medRxiv preprint doi: https://doi.org/10.1101/2021.04.16.21255516; this version posted April 20, 2021. The copyright holder for this preprint

(which was not certified by peer review) is the author/funder, who has granted medRxiv a license to display the preprint in perpetuity.

All rights reserved. No reuse allowed without permission.

\title{
Exaggerated Right Ventricular Dysfunction in Females with Group 3 Pulmonary Hypertension
}

Sasha Z. Prisco, MD, $\mathrm{PhD}^{1}$, Felipe Kazmirczak, MD¹, Kurt W. Prins, MD, $\mathrm{PhD}^{1, *}$, and Thenappan Thenappan,

$$
\mathrm{MD}^{1 . *}
$$

1. Cardiovascular Division, Lillehei Heart Institute, Department of Medicine, University of Minnesota, Minneapolis, MN

${ }^{*}$ Co-corresponding authors

ORCIDs: SZP (https://orcid.org/0000-0002-9059-0635), FK (https://orcid.org/0000-0001-8998-7259), KWP (https://orcid.org/0000-0002-0364-6742), TT (https://orcid.org/0000-0002-6210-0467)

Running Title: Right Ventricular Dysfunction in Group 3 Pulmonary Hypertension Females Total Word Count: 1000

\section{Authors for Correspondences}

Thenappan Thenappan, MD

Associate Professor of Medicine

Cardiovascular Division

University of Minnesota

Email: tthenapp@umn.edu

Twitter: @thenappanMD
Kurt Prins, MD, PhD

Assistant Professor of Medicine

Cardiovascular Division

Lillehei Heart Institute

University of Minnesota

Email: prin0088@umn.edu

Twitter: @kurt_prins 
medRxiv preprint doi: https://doi.org/10.1101/2021.04.16.21255516; this version posted April 20, 2021. The copyright holder for this preprint (which was not certified by peer review) is the author/funder, who has granted medRxiv a license to display the preprint in perpetuity. All rights reserved. No reuse allowed without permission.

\section{List of non-standard abbreviations}

mPAP Mean pulmonary arterial pressure

PAC Pulmonary arterial compliance

PAH Pulmonary arterial hypertension

$\mathrm{PH} \quad$ Pulmonary hypertension

PVR Pulmonary vascular resistance

RV Right ventricle/ventricular

RVD Right ventricular dysfunction

RVFAC Right ventricular fractional area change 


\section{Abstract}

Group 3 pulmonary hypertension $(\mathrm{PH})$ patients have disproportionate right ventricular dysfunction (RVD) as compared to pulmonary arterial hypertension (PAH) patients, but the cause of the divergent RV phenotypes is unknown. One potential mechanism may be biological sex as females have better RV function than males. However, the combined effects of $\mathrm{PH}$ type and sex on RV function are unexplored. Therefore, we evaluated how sex and PH etiology modulated RVD in a single-center cohort study. Male sex was not associated with significant differences in RV function when comparing PH etiologies. However, female Group 3 patients had more pronounced RVD than female PAH patients. In particular, Group 3 females had marked reduction in RV function when pulmonary vascular resistance was matched. Group 3 females were older than PAH females, but the exaggerated RVD was still observed in postmenopausal (age $\geq 55$ ) Group 3 females. This suggests lung disease exacerbates RVD in Group 3 females. 
medRxiv preprint doi: https://doi.org/10.1101/2021.04.16.21255516; this version posted April 20, 2021. The copyright holder for this preprint (which was not certified by peer review) is the author/funder, who has granted medRxiv a license to display the preprint in perpetuity.

All rights reserved. No reuse allowed without permission.

Pulmonary hypertension $(\mathrm{PH})$ due to chronic lung disease (Group $3 \mathrm{PH}$ ) is the second most common cause of $\mathrm{PH}(1)$, and Group $3 \mathrm{PH}$ patients have the worst survival rates of all the $\mathrm{PH}$ etiologies(2). An important prognostic factor in Group $3 \mathrm{PH}$ is the presence of right ventricular dysfunction (RVD), as RVD results in heightened rates of heart failure hospitalization and death(3). Interestingly, Group $3 \mathrm{PH}$ patients have worse RV function despite having less severe $\mathrm{PH}$ when compared to pulmonary arterial hypertension (PAH) patients(4). Currently, the mechanisms underlying the disproportionate RVD in Group 3 PH patients are unknown. A deeper understanding of this observation is important because this patient population has limited treatment options.

One potential explanation for the disproportionate RVD in Group $3 \mathrm{PH}$ may be biological sex as Group $3 \mathrm{PH}$ does not have a female predominance like $\mathrm{PAH}$ does(5), and multiple studies reveal females have superior RV function when compared to males(6). However, the potential synergetic effects of PH etiology and biological sex on RV function in $\mathrm{PH}$ patients are unexplored. Therefore, we examined how $\mathrm{PH}$ type impacted RV function in males and females.

\section{Methods}

Group $1 \mathrm{PAH}$ and Group $3 \mathrm{PH}$ patients were identified from the Minnesota PH Repository(7) and were defined according to the World Health Organization criteria as outlined by the 6th World Symposium on $\mathrm{PH}(8)$. We used pulmonary function tests, high resolution computed tomography, and sleep studies to define Group 3 $\mathrm{PH}$. RV fractional area change (RVFAC) was quantified from offline transthoracic echocardiograms by two reviewers (FK and KWP). Invasive hemodynamics confirmed $\mathrm{PH}$ diagnosis (mean pulmonary arterial pressure [mPAP]>20 mm Hg). We evaluated the relationship between RVFAC and pulmonary vascular resistance (PVR) based on sex and PH etiology. PVR was defined as (mPAP - pulmonary capillary wedge pressure)/ cardiac output. Pulmonary arterial compliance (PAC) was calculated as stroke volume divided by pulmonary arterial pulse pressure. Statistical analysis was performed on GraphPad Prism version 9.0.0. Unpaired $t$-test compared means of two groups. If variance was unequal, Mann-Whitney $U$ test was completed. Fisher's exact test evaluated differences in categorical variables. Data are presented as mean \pm standard deviation. 
medRxiv preprint doi: https://doi.org/10.1101/2021.04.16.21255516; this version posted April 20, 2021. The copyright holder for this preprint (which was not certified by peer review) is the author/funder, who has granted medRxiv a license to display the preprint in perpetuity.

All rights reserved. No reuse allowed without permission.

\section{Results}

We identified $217 \mathrm{PAH}$ (60 males and 157 females) and 233 Group $3 \mathrm{PH}$ patients (105 males and 128 females) for our analysis (Supplemental Table). Group $3 \mathrm{PH}$ patients were older than PAH patients in both male (Group 3: $67 \pm 11$ years vs. Group 1: $53 \pm 13$ years, $p<0.0001$ ) and female sexes (Group 3: $64 \pm 11$ vs.

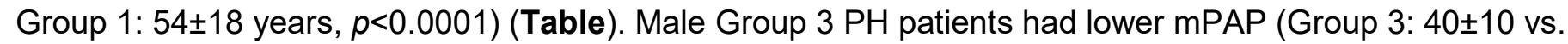
Group 1: $47 \pm 16 \mathrm{mmHg}, p=0.007)$ with a trend for lower PVR (Group 3: $6.5 \pm 3.4$ vs. Group 1: 7.5 $\pm 4.2 \mathrm{WU}$, $p=0.09$ ) compared to PAH males (Table). Although there was no difference in mPAP between female Group 3

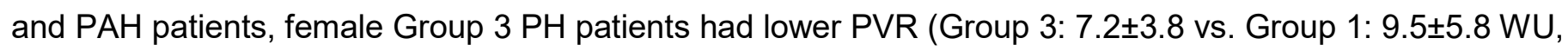
$p=0.002)$. There were no differences in PAC between Group 1 and $3 \mathrm{PH}$ patients within the same sex. In summary, Group 3 patients had either similar or less severe pulmonary vascular disease compared to PAH patients of the same sex.

Consistent with previous results(6), males had more impaired RV function than females in both $\mathrm{PH}$ types (Figure 1A-B). Next, we evaluated how PH etiology affected RV function in both sexes. There were no differences in RVFAC (Group 3: $27 \pm 10 \%$ vs. Group 1: $28 \pm 10 \%, p=0.63)$ or RVFAC relative to PVR $(p=0.08$ between y-intercepts, $p=0.74$ between slopes) between Group $3 \mathrm{PH}$ and PAH males (Figure 1C-D). In contrast, female Group $3 \mathrm{PH}$ patients had significantly lower RVFAC compared to female PAH patients (Group 3: $32 \pm 11 \%$ vs. Group 1: $35 \pm 10 \%, p=0.049$ ) (Figure 1E). Group 3 females exhibited heightened sensitivity to RV afterload when compared to PAH females as RVFAC was lower at all PVR levels, and they had a more accentuated reduction in RV function as PVR increased ( $p=0.0005$ between $y$-intercepts and $p=0.05$ between slopes) (Figure 1F). Importantly, postmenopausal (age 255 ) Group 3 females had more severe RVD than postmenopausal PAH females when PVR was matched (Figure 2).

\section{Discussion}

Here, we show females with Group $3 \mathrm{PH}$ have exaggerated RVD when compared to PAH females, but male sex was not associated with differences in RV phenotype when comparing the two PH types. The biological basis for worse RV function in Group $3 \mathrm{PH}$ females is uncertain, but age and the presence of lung 
medRxiv preprint doi: https://doi.org/10.1101/2021.04.16.21255516; this version posted April 20, 2021. The copyright holder for this preprint (which was not certified by peer review) is the author/funder, who has granted medRxiv a license to display the preprint in perpetuity. All rights reserved. No reuse allowed without permission.

disease are likely contributors. The older age in Group 3 females would lead to a higher proportion of postmenopausal patients, and that would ultimately result in lower estradiol levels. Estradiol is known to augment RV function as higher estradiol levels are associated with enhanced RV function(5). Moreover, preclinical studies show estrogen directly preserves RV function in rodent $\operatorname{PAH}(9,10)$. However, potential differences in estradiol may not be the only contributor to worse RV function in Group 3 females as postmenopausal Group 3 females had more severe RVD compared to postmenopausal PAH patients. Thus, the presence of chronic lung disease likely exacerbates RVD in females with Group $3 \mathrm{PH}$.

Our study has important limitations that must be acknowledged. First, this was a single-center study. Second, we were unable to calculate RVFAC for all patients due to the quality of the echocardiographic images. Third, we may not have had the power to detect differences in RV function in males as there was a trend for worse RV function in male Group $3 \mathrm{PH}$ compared to PAH males when we plotted RVFAC relative to PVR. Finally, our sample size was too small to determine whether there are differences in RV function between pre- and postmenopausal Group 3 females. We only had RVFAC data for six peri- to premenopausal $(<50$ years) Group 3 females, but there was similar RVFAC when compared to $32 \mathrm{PAH}$ females $<50$ years (Group 3 : $35.7 \pm 4.7 \%$ vs. Group 1: $35.5 \pm 9.7 \%)$.

In summary, we show female Group $3 \mathrm{PH}$ patients have inferior RV function compared to female PAH patients. Chronic lung disease and decreased estradiol levels due to aging likely underlie these findings.

Financial conflicts of interest: KWP served on an advisory board for Actelion and Edwards and receives grant funding from United Therapeutics. TT served on an advisory board for Actelion, United Therapeutics, Altavant Sciences, and Aria CV. TT receives research funding for clinical trials from United Therapeutics, Aria CV, GossimerBio, and Acceleron. The other authors have declared that no conflict of interest exists.

Funding: SZP is funded by NIH T32 HL144472, a University of Minnesota Clinical and Translational Science award (NIH UL1 TR002494), and a University of Minnesota Medical School Academic Investment Educational Program Grant; KWP is funded by NIH K08 HL140100, the Cardiovascular Medical Research and Education Fund, a Lillehei Heart Institution Cardiovascular Seed Grant, the University of Minnesota Faculty Research 
medRxiv preprint doi: https://doi.org/10.1101/2021.04.16.21255516; this version posted April 20, 2021. The copyright holder for this preprint (which was not certified by peer review) is the author/funder, who has granted medRxiv a license to display the preprint in perpetuity.

All rights reserved. No reuse allowed without permission.

Development Grant, and the United Therapeutics Jenesis Award; TT is funded by the Cardiovascular Medical

Research and Education Fund and the University of Minnesota Futures Grant.

Author Contributions: All authors made substantial contributions to the conception and design of the work.

SZP, FK, and KWP completed the data acquisition and analysis. SZP and KWP drafted the manuscript. All authors revised the manuscript and approved the final version of the manuscript. 
medRxiv preprint doi: https://doi.org/10.1101/2021.04.16.21255516; this version posted April 20, 2021. The copyright holder for this preprint

(which was not certified by peer review) is the author/funder, who has granted medRxiv a license to display the preprint in perpetuity.

All rights reserved. No reuse allowed without permission.

\section{References}

1. Wijeratne DT, Lajkosz K, Brogly SB, et al.: Increasing Incidence and Prevalence of World Health Organization Groups 1 to 4 Pulmonary Hypertension: A Population-Based Cohort Study in Ontario, Canada. Circ Cardiovasc Qual Outcomes 2018;11:e003973.

2. Gall H, Felix JF, Schneck FK, et al.: The Giessen Pulmonary Hypertension Registry: Survival in pulmonary hypertension subgroups. J Heart Lung Transplant 2017.

3. Prins KW, Rose L, Archer SL, et al.: Clinical Determinants and Prognostic Implications of Right Ventricular Dysfunction in Pulmonary Hypertension Caused by Chronic Lung Disease. J Am Heart Assoc 2019;8:e011464.

4. Prins KW, Rose L, Archer SL, et al.: Disproportionate Right Ventricular Dysfunction and Poor Survival in Group 3 Pulmonary Hypertension. Am J Respir Crit Care Med 2018;197:1496-9.

5. Ventetuolo CE, Ouyang P, Bluemke DA, et al.: Sex hormones are associated with right ventricular structure and function: The MESA-right ventricle study. Am J Respir Crit Care Med 2011;183:659-67.

6. Hester J, Ventetuolo C, Lahm T: Sex, Gender, and Sex Hormones in Pulmonary Hypertension and Right Ventricular Failure. Compr Physiol 2019;10:125-70.

7. $\quad$ Prins KW, Weir EK, Archer SL, et al.: Pulmonary pulse wave transit time is associated with right ventricular-pulmonary artery coupling in pulmonary arterial hypertension. Pulm Circ 2016;6:576-85.

8. Galiè N, McLaughlin VV, Rubin LJ, Simonneau G: An overview of the 6th World Symposium on Pulmonary Hypertension. Eur Respir J 2019;53.

9. Frump AL, Albrecht M, Yakubov B, et al.: 17ß-Estradiol and estrogen receptor a protect right ventricular function in pulmonary hypertension via BMPR2 and apelin. J Clin Invest 2021;131.

10. Lahm T, Frump AL, Albrecht ME, et al.: $17 \beta$-Estradiol mediates superior adaptation of right ventricular function to acute strenuous exercise in female rats with severe pulmonary hypertension. Am J Physiol Lung Cell Mol Physiol 2016;311:L375-88. 
Table: Clinical characteristics of the Group $1 \mathrm{PAH}$ and Group $3 \mathrm{PH}$ cohorts by sex.

\begin{tabular}{|c|c|c|c|c|c|c|}
\hline Characteristics & $\begin{array}{l}\text { Male Group } 1 \\
(n=60)\end{array}$ & $\begin{array}{l}\text { Male Group } 3 \\
(n=105)\end{array}$ & $P$-value & $\begin{array}{c}\text { Female Group } 1 \\
(n=157)\end{array}$ & $\begin{array}{c}\text { Female Group } 3 \\
(n=128)\end{array}$ & $P$-value \\
\hline Age, years & $53 \pm 13$ & $67 \pm 11$ & $<0.0001$ & $54 \pm 18$ & $64 \pm 11$ & $<0.0001$ \\
\hline \multicolumn{7}{|l|}{ PH etiology, n (\%) } \\
\hline Idiopathic PAH & $9(15 \%)$ & - & & $38(24.2 \%)$ & & \\
\hline Heritable PAH & $1(1.7 \%)$ & - & & $1(0.6 \%)$ & & \\
\hline Drug-induced PAH & $7(11.6 \%)$ & - & & $6(4 \%)$ & & \\
\hline CTD-associated PAH & $11(18.3 \%)$ & - & & $77(49 \%)$ & & \\
\hline HIV-associated PAH & $2(3.3 \%)$ & - & & $1(0.6 \%)$ & & \\
\hline Portopulmonary PAH & $16(26.7 \%)$ & - & & $17(11 \%)$ & & \\
\hline Congenital heart disease & $12(20 \%)$ & - & & $13(8 \%)$ & & \\
\hline PVOD & $1(1.7 \%)$ & - & & $1(0.6 \%)$ & & \\
\hline Other & $1(1.7 \%)$ & - & & $3(2 \%)$ & & \\
\hline COPD & - & $37(35 \%)$ & & & $58(45 \%)$ & \\
\hline ILD & - & $42(40 \%)$ & & & $53(41.4 \%)$ & \\
\hline OSA & - & $7(7 \%)$ & & & $10(8 \%)$ & \\
\hline Alveolar hypoventilation disorders & - & $1(1 \%)$ & & & $3(2.3 \%)$ & \\
\hline CPFE & - & $18(17 \%)$ & & & $3(2.3 \%)$ & \\
\hline Other & - & $0(0 \%)$ & & & $1(1 \%)$ & \\
\hline \multicolumn{7}{|l|}{ Laboratory } \\
\hline Serum creatinine, $\mathrm{mg} / \mathrm{dL}$ & $1.3 \pm 1.2(n=60)$ & $1.2 \pm 0.7(n=104)$ & 0.08 & $1.0 \pm 0.7(n=155)$ & $0.8 \pm 0.4(n=125)$ & 0.006 \\
\hline Serum hemoglobin, g/dL & $14.2 \pm 2.9(n=59)$ & $13.9 \pm 2.2(n=104)$ & 0.42 & $12.9 \pm 2.4(n=153)$ & $13.2 \pm 1.9(n=125)$ & 0.13 \\
\hline Serum NT-proBNP, pg/dL & $\begin{array}{c}2281 \pm 5213 \\
(n=48)\end{array}$ & $\begin{array}{c}2394 \pm 3200 \\
(n=90)\end{array}$ & 0.03 & $\begin{array}{c}2828 \pm 6115 \\
(n=135)\end{array}$ & $\begin{array}{c}2537 \pm 3836 \\
(n=112)\end{array}$ & 0.89 \\
\hline Six-minute walk distance, $\mathrm{m}$ & $375 \pm 125(n=24)$ & $245 \pm 117(n=65)$ & $<0.0001$ & $329 \pm 127(n=97)$ & $218 \pm 100(n=81)$ & $<0.0001$ \\
\hline \multicolumn{7}{|l|}{ Echocardiography } \\
\hline RVFAC, \% & $28 \pm 10(n=34)$ & $27 \pm 10(n=48)$ & 0.63 & $35 \pm 10(n=92)$ & $32 \pm 11(n=62)$ & 0.049 \\
\hline TAPSE, $\mathrm{cm}$ & $1.8 \pm 0.5(n=32)$ & $1.9 \pm 0.9(n=54)$ & 0.93 & $1.9 \pm 0.6(n=107)$ & $1.8 \pm 0.4(n=75)$ & 0.47 \\
\hline $\mathrm{S}^{\prime}, \mathrm{cm} / \mathrm{s}$ & $10.2 \pm 2.2(n=22)$ & $10.6 \pm 3.7(n=38)$ & 0.46 & $10.7 \pm 2.7(n=78)$ & $11.2 \pm 2.4(n=47)$ & 0.29 \\
\hline \multicolumn{7}{|l|}{ Hemodynamics } \\
\hline Heart rate, beats/min & $74 \pm 15(n=47)$ & $77 \pm 17(n=87)$ & 0.36 & $79 \pm 15(n=135)$ & $78 \pm 14(n=95)$ & 0.60 \\
\hline Mean right atrial pressure, $\mathrm{mmHg}$ & $7 \pm 4(n=59)$ & $8 \pm 4(n=99)$ & 0.20 & $8 \pm 5(n=153)$ & $8 \pm 5(n=111)$ & 0.90 \\
\hline Mean pulmonary artery pressure, $\mathrm{mmHg}$ & $47 \pm 16(n=60)$ & $40 \pm 10(n=100)$ & 0.007 & $44 \pm 13(n=156)$ & $42 \pm 12(n=113)$ & 0.27 \\
\hline Pulmonary capillary wedge pressure, $\mathrm{mmHg}$ & $10 \pm 3(n=60)$ & $12 \pm 4(n=98)$ & 0.007 & $9 \pm 4(n=157)$ & $12 \pm 6(n=111)$ & 0.001 \\
\hline Cardiac output, L/min & $5.9 \pm 2.1(n=43)$ & $5.1 \pm 1.5(n=78)$ & 0.048 & $4.5 \pm 1.7(n=112)$ & $4.8 \pm 1.4(n=92)$ & 0.13 \\
\hline Cardiac index, $\mathrm{L} / \mathrm{min} / \mathrm{m}^{2}$ & $2.8 \pm 0.9(n=41)$ & $2.5 \pm 0.9(n=76)$ & 0.12 & $2.5 \pm 0.9(n=112)$ & $2.6 \pm 0.7(n=90)$ & 0.31 \\
\hline Pulmonary vascular resistance, Wood units & $7.5 \pm 4.2(n=53)$ & $6.5 \pm 3.4(n=97)$ & 0.09 & $9.5 \pm 5.8(n=150)$ & $7.2 \pm 3.8(n=112)$ & 0.002 \\
\hline Pulmonary arterial compliance, $\mathrm{mL} / \mathrm{mmHg}$ & $2.2 \pm 1.5(n=44)$ & $2.1 \pm 1.1(n=86)$ & 0.85 & $1.6 \pm 1.0(n=132)$ & $1.8 \pm 1.0(n=95)$ & 0.17 \\
\hline
\end{tabular}


COPD: chronic obstructive pulmonary disease, CPFE: combined pulmonary fibrosis and emphysema, CTD: connective tissue disease, HIV: human immunodeficiency virus, ILD: interstitial lung disease, NT-proBNP: N-terminal pro-brain natriuretic peptide, OSA: obstructive sleep apnea, PAH:

pulmonary arterial hypertension, $\mathrm{PH}$ : pulmonary hypertension, PVOD: pulmonary veno-occlusive disease, RVFAC: right ventricular fractional area change, S': tricuspid annular peak systolic velocity, TAPSE: tricuspid annular plane systolic excursion. 
Figure 1: Group 3 females have exaggerated RV dysfunction compared to PAH females. Males with Group 1 $\mathrm{PAH}(\mathbf{A})$ and Group $3 \mathrm{PH}(\mathbf{B})$ had significantly decreased RVFAC compared to females. (C) Group $3 \mathrm{PH}$ males had similar RVFAC compared to Group 1 PAH males. (D) There was no statistical difference in the relationship between RVFAC and PVR between Group 1 and Group 3 males ( $p=0.08$ when comparing y-intercepts and $p=0.74$ when comparing slopes). (E) Female Group $3 \mathrm{PH}$ patients had significantly worse RV function compared to female Group $1 \mathrm{PAH}$ patients. (F) Group $3 \mathrm{PH}$ females had inferior RV function at all PVR levels $(p=0.0005$ when comparing y-intercepts and $p=0.05$ when comparing slopes). $\mathrm{PAH}$ : pulmonary arterial hypertension, $\mathrm{PH}$ : pulmonary hypertension, PVR: pulmonary vascular resistance, RVFAC: right ventricular fractional area change, WU: Wood units.

A

Group 1 PAH

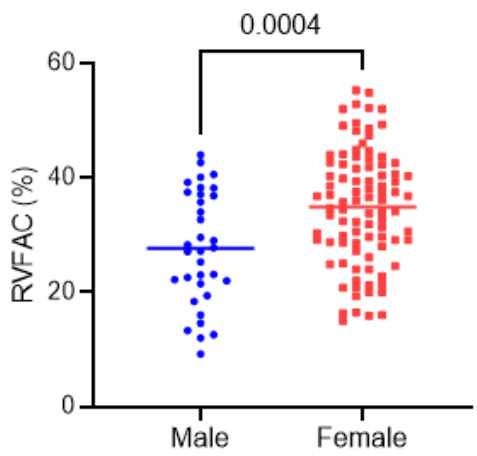

C

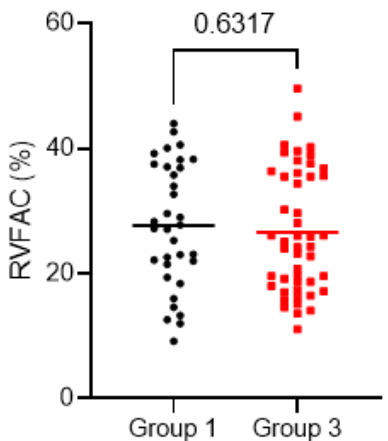

E

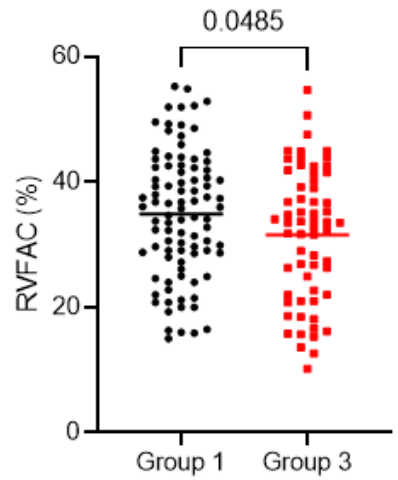

F
B

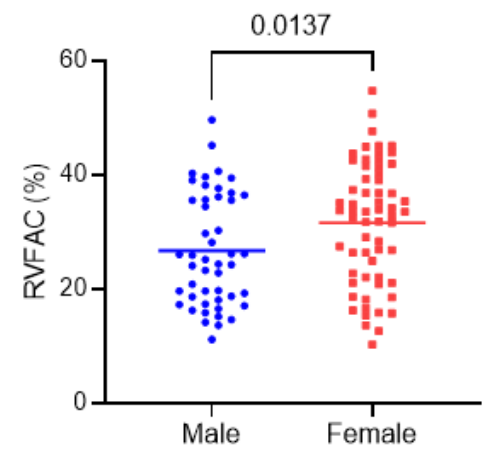

Group $3 \mathrm{PH}$
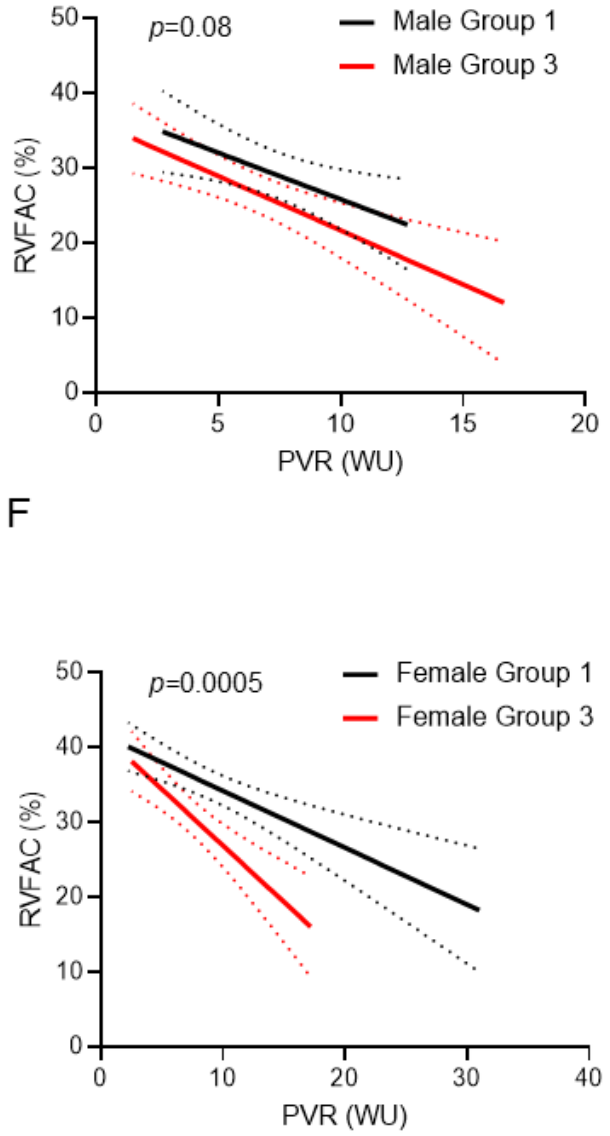
medRxiv preprint doi: https://doi.org/10.1101/2021.04.16.21255516; this version posted April 20, 2021. The copyright holder for this preprint (which was not certified by peer review) is the author/funder, who has granted medRxiv a license to display the preprint in perpetuity.

All rights reserved. No reuse allowed without permission.

Figure 2: Postmenopausal Group 3 females have worse RV function compared to postmenopausal PAH females. (A) There was a non-statistically significant reduction in RVFAC between postmenopausal Group 3 females as compared to postmenopausal PAH females (Group 3: 31.1\% [10.2-54.7\%] vs. Group 1: 34.6\% [15.0-55.3\%], data presented as mean [range]). (B) Postmenopausal Group $3 \mathrm{PH}$ females had inferior RV function at all PVR levels ( $p=0.0014$ when comparing y-intercepts and $p=0.06$ when comparing slopes).

A

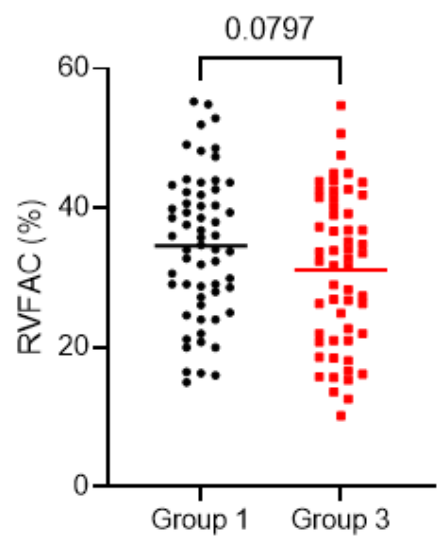

B

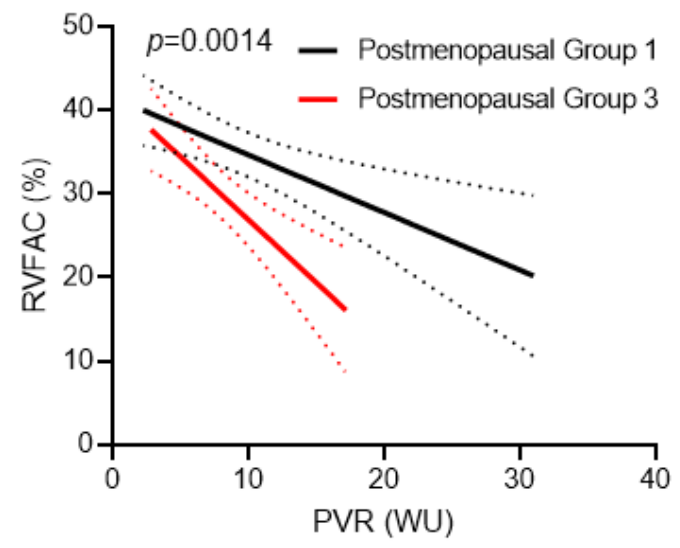


medRxiv preprint doi: https://doi.org/10.1101/2021.04.16.21255516; this version posted April 20, 2021. The copyright holder for this preprint (which was not certified by peer review) is the author/funder, who has granted medRxiv a license to display the preprint in perpetuity. All rights reserved. No reuse allowed without permission.

Supplemental Table: Clinical characteristics of the Group 1 PAH and Group 3 PH cohorts.

\begin{tabular}{|c|c|c|c|}
\hline Characteristics & Group $1(n=217)$ & Group $3(n=233)$ & $P$-value \\
\hline Age, years & $54 \pm 16$ & $65 \pm 11$ & $<0.0001$ \\
\hline Female sex, n (\%) & $157(72 \%)$ & $128(55 \%)$ & 0.0001 \\
\hline \multicolumn{4}{|l|}{ PH etiology, n (\%) } \\
\hline Idiopathic PAH & $47(22 \%)$ & - & \\
\hline Heritable PAH & $2(1 \%)$ & - & \\
\hline Drug-induced PAH & $13(6 \%)$ & - & \\
\hline CTD-associated PAH & $88(40 \%)$ & - & \\
\hline HIV-associated PAH & $3(1 \%)$ & - & \\
\hline Portopulmonary PAH & $33(15 \%)$ & - & \\
\hline Congenital heart disease & $25(12 \%)$ & - & \\
\hline PVOD & $2(1 \%)$ & - & \\
\hline Other & $4(2 \%)$ & - & \\
\hline COPD & - & $95(40.8 \%)$ & \\
\hline ILD & - & $95(40.8 \%)$ & \\
\hline OSA & - & $17(7 \%)$ & \\
\hline Alveolar hypoventilation disorders & - & $4(2 \%)$ & \\
\hline CPFE & - & $21(9 \%)$ & \\
\hline Other & - & $1(0.4 \%)$ & \\
\hline \multicolumn{4}{|l|}{ Laboratory } \\
\hline Serum creatinine, $\mathrm{mg} / \mathrm{dL}$ & $1.1 \pm 0.8(n=215)$ & $1.0 \pm 0.6(n=229)$ & 0.93 \\
\hline Serum hemoglobin, g/dL & $13.2 \pm 2.6(n=212)$ & $13.5 \pm 2.1(n-229)$ & 0.14 \\
\hline Serum NT-proBNP, pg/dL & $2684 \pm 5882(n=183)$ & $2537 \pm 3836(n=112)$ & 0.65 \\
\hline Six-minute walk distance, $\mathrm{m}$ & $338 \pm 127(n=121)$ & $230 \pm 108(n=146)$ & $<0.0001$ \\
\hline \multicolumn{4}{|l|}{ Echocardiography } \\
\hline RVFAC, $\%$ & $33 \pm 10(n=126)$ & $29 \pm 11(n=110)$ & 0.01 \\
\hline TAPSE, cm & $1.9 \pm 0.5(n=139)$ & $1.9 \pm 0.7(n=129)$ & 0.50 \\
\hline $\mathrm{S}^{\prime}, \mathrm{cm} / \mathrm{s}$ & $10.6 \pm 2.6(n=100)$ & $10.9 \pm 3.0(n=85)$ & 0.39 \\
\hline \multicolumn{4}{|l|}{ Hemodynamics } \\
\hline Heart rate, beats/min & $77 \pm 15(n=182)$ & $77 \pm 15(n=182)$ & 0.88 \\
\hline Mean right atrial pressure, $\mathrm{mmHg}$ & $8 \pm 5(n=212)$ & $8 \pm 5(n=210)$ & 0.60 \\
\hline Mean pulmonary artery pressure, $\mathrm{mmHg}$ & $45 \pm 14(n=216)$ & $41 \pm 11(n=213)$ & 0.006 \\
\hline Pulmonary capillary wedge pressure, $\mathrm{mmHg}$ & $9 \pm 3(n=217)$ & $12 \pm 6(n=209)$ & $<0.0001$ \\
\hline Cardiac output, L/min & $4.9 \pm 1.9(n=155)$ & $4.9 \pm 1.5(n=170)$ & 0.53 \\
\hline Cardiac index, $\mathrm{L} / \mathrm{min} / \mathrm{m}^{2}$ & $2.6 \pm 0.9(n=153)$ & $2.6 \pm 0.8(n=166)$ & 1.00 \\
\hline Pulmonary vascular resistance, Wood units & $7.5 \pm 4.2(n=53)$ & $6.9 \pm 3.7(n=209)$ & 0.27 \\
\hline Pulmonary arterial compliance, $\mathrm{mL} / \mathrm{mmHg}$ & $1.7 \pm 1.1(n=176)$ & $1.9 \pm 1.1(n=181)$ & 0.09 \\
\hline
\end{tabular}

